\title{
Target-Specific Suppression of GABA Release from Parvalbumin Interneurons in the Basolateral Amygdala by Dopamine
}

\author{
Hong-Yuan Chu, ${ }^{1}$ Wataru Ito, ${ }^{1}$ Jiayang $\mathrm{Li},{ }^{1}$ and Alexei Morozov ${ }^{1,2}$ \\ ${ }^{1}$ Unit on Behavioral Genetics, Laboratory of Molecular Pathophysiology, National Institute of Mental Health, National Institutes of Health, Bethesda, \\ Maryland 20892, and ${ }^{2}$ Virginia Tech Carilion Research Institute, Virginia Tech, Roanoke, Virginia 24016
}

\begin{abstract}
Dopamine (DA) in the basolateral amygdala (BLA) promotes fear learning by disinhibiting principal neurons (PNs) and enabling synaptic plasticity in their sensory inputs. While BLA interneurons (INs) are heterogeneous, it is unclear which interneuron subtypes decrease GABAergic input to PNs in the presence of DA. Here, using cell type-selective photostimulation by channelrhodopsin 2 in BLA slices from mouse brain, we examined the role of parvalbumin-positive INs (PV-INs), the major interneuronal subpopulation in BLA, in the disinhibitory effect of DA. We found that DA selectively suppressed GABAergic transmission from PV-INs to PNs by acting on presynaptic $\mathrm{D}_{2}$ receptors, and this effect was mimicked by Rp-cAMP, an inhibitor of cAMP-dependent signaling. In contrast, DA did not alter GABA release from PV-INs to INs. Furthermore, neither suppressing cAMP-dependent signaling by Rp-cAMP nor enhancing it by forskolin altered GABA release from PV-INs to BLA INs. Overall, DA disinhibits BLA, at least in part, by suppressing GABA release from PV-INs in the target cell-specific manner that results from differential control of this release by cAMP-dependent signaling.
\end{abstract}

\section{Introduction}

The basolateral amygdala (BLA) is the major information entry site of the amygdala complex (LeDoux, 2000). It is regulated by dopamine (DA) released from dopaminergic axons originating from the midbrain areas (Asan, 1997). Stressful events enhance DA release in BLA (Harmer and Phillips, 1999; Inglis and Moghaddam, 1999; Suzuki et al., 2002), which facilitates formation of fear memories (Fadok et al., 2009), presumably by attenuating feedforward inhibition (FFI) of BLA principal neurons (PNs) and enabling LTP induction at sensory afferents (Rosenkranz and Grace, 2001; Bissière et al., 2003; Marowsky et al., 2005). However, very little is known about the identity of interneurons (INs) that mediate dopaminergic disinhibition. Yet this information is important for understanding the disinhibition mechanisms, because individual interneuronal subtypes control principal cell activity by releasing GABA onto BLA PNs in temporally and spatially distinct patterns (Freund and Katona, 2007; Bienvenu et al., 2012).

Local INs in BLA are heterogeneous; they differ in morphological, electrophysiological, and neurochemical characteristics (Sosulina et al., 2010; Spampanato et al., 2011). Among them,

\footnotetext{
Received June 25, 2012; revised Aug. 28, 2012; accepted Aug. 31, 2012.

Author contributions: H.-Y.C., W.I., and A.M. designed research; H.-Y.C. and J.L. performed research; H.-Y.C. analyzed data; H.-Y.C., W.I., and A.M. wrote the paper.

This work was supported by the National Institute of Mental Health intramural research program. We thank Victor Luna for commenting on the manuscript.

Correspondence should be addressed to either Alexei Morozov or Hong-Yuan Chu, Unit on Behavioral Genetics, Laboratory of Molecular Pathophysiology, National Institute of Mental Health, National Institutes of Health, 35 Convent Drive, Bethesda, Maryland 20892, E-mail: alexeim@vtc.vt.edu or hongyuan.chu@gmail.com.

DOI:10.1523/JNEUROSCI.2997-12.2012

Copyright $\odot 2012$ the authors $\quad 0270-6474 / 12 / 3214815-06 \$ 15.00 / 0$
}

parvalbumin-positive INs (PV-INs) constitute $\sim 40 \%$ and exert robust perisomatic inhibition of PNs (McDonald and Betette, 2001). PV-INs are also the major target of dopaminergic fibers in BLA (Pinard et al., 2008). Given these properties, we took advantage of a PV-IN-specific Cre line of transgenic mice (Hippenmeyer et al., 2005) and tested the role of PV-INs in dopaminergic disinhibition of BLA PNs using selective photoactivation of PVINs expressing channelrhodopsin 2 (ChR2).

\section{Materials and Methods}

Stereotactic injections. Adeno-associated virus (AAV) pseudo-type 1 (titer of $10^{12}$ particles per milliliter) containing Cre-activated ChR2 gene was prepared by University of North Carolina Gene Therapy Vector Core (Chapel Hill, NC) using Addgene plasmids 20298 (pAAV-EF1a-double floxed-hChR2(H134R)-EYFP-WPRE-HGHpA) (Zhang et al., 2010) and 18917 (AAV-FLEX-rev-ChR2-tdTomato) (Aponte et al., 2011).

Three- to 4-week-old male Cre-PV/GAD67-GFP or Cre-SOM/ GAD67-GFP double-positive transgenic mice (Tamamaki et al., 2003; Hippenmeyer et al., 2005; Taniguchi et al., 2011) on C57BL/6J background were injected bilaterally with $0.5 \mu \mathrm{l}$ of virus into BLA [coordinates from bregma (in $\mathrm{mm}$ ): $\mathrm{AP}-1.7 ; \mathrm{ML} \pm 3.3 ; \mathrm{DV}-3.8$ from the brain surface] following the National Institute of Mental Health Animal Care and Use Committee-approved protocol. Experiments were performed 3-4 weeks after surgery.

Electrophysiology and photostimulation. Animals were anesthetized with isoflurane and decapitated. Brain was quickly removed, and coronal amygdala slices $(300 \mu \mathrm{m})$ were cut using DSK Microslicer (Ted Pella) in ice-cold partial sucrose artificial CSF (ACSF) containing the following (in mM): $80 \mathrm{NaCl}, 3.5 \mathrm{KCl}, 4.5 \mathrm{MgSO}_{4}, 0.5 \mathrm{CaCl}_{2}, 1.25 \mathrm{NaH}_{2} \mathrm{PO}_{4}, 23$ $\mathrm{NaHCO}_{3}, 10$ glucose, and 90 sucrose equilibrated with $95 \% \mathrm{O}_{2} / 5 \% \mathrm{CO}_{2}$. The slices were incubated in the same sucrose ACSF at room temperature for $1 \mathrm{~h}$ before recording, then transferred to a recording chamber superfused at $2 \mathrm{ml} / \mathrm{min}$ with ACSF, bubbled with $95 \% \mathrm{O}_{2} / 5 \% \mathrm{CO}_{2}$, containing 

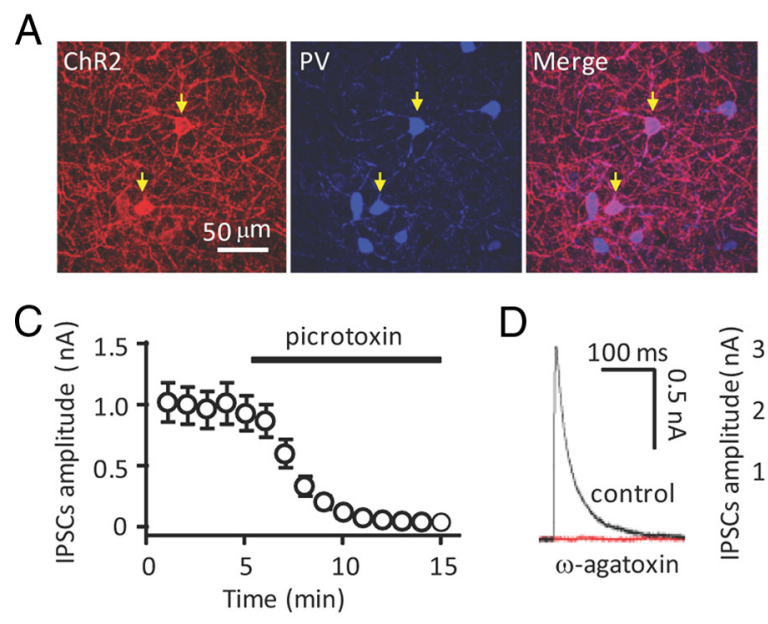
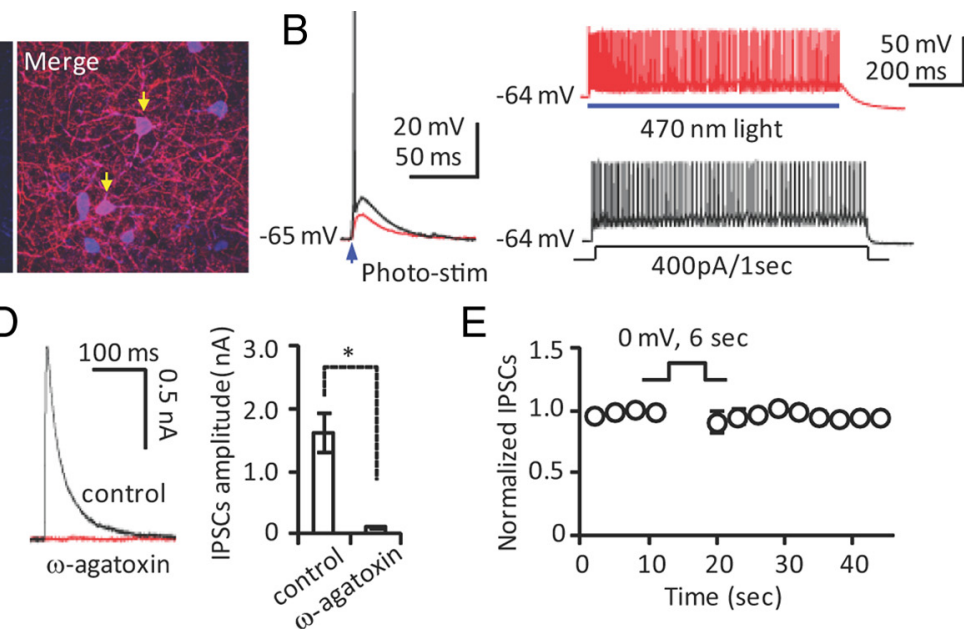

Figure 1. Selective activation of GABAergic transmission between PV-INs and PNs in BLA by ChR2. A, Confocal images show ChR2-tdTomato fluorescence (red) and PV-immunofluorescence (blue). Note that all ChR2-expressing cells (arrows) express PV, but only $41 \pm 4 \%$ of PV-INs ( $n=4$ mice) express ChR2. B, Left, Whole-cell recording from a ChR2-expressing neuron. Short pulses of photostimulation (Photo-stim) evoke membrane depolarization (red, $0.2 \mathrm{~ms}$ pulse) and action potential (black, $0.4 \mathrm{~ms}$ pulse). Right, Trains of action potentials induced by continuous photostimulation (red, firing frequency $=107 \mathrm{~Hz}$ ) or by current injection (black, firing frequency $=70 \mathrm{~Hz}$ ). $\boldsymbol{C}$, Blockade of light-induced IPSCs by GABA , receptor antagonist picrotoxin. $\boldsymbol{D}$, Blockade of light-induced IPSCs by P/Q type $\mathrm{Ca}^{2+}$ channel blocker $\omega$-agatoxin IVA. Left, IPSCs examples before (black) and after (red) $\omega$-agatoxin IVA application. Right, Summary bar graph shows the blockade of light-induced IPSCs by $\omega$-agatoxin IVA ( $\left.{ }^{*} p<0.05\right)$. E, Lack of DSI in light-induced IPSCs by a 6 s depolarization to $0 \mathrm{mV}$.

the following (in mM): $125 \mathrm{NaCl}, 2.5 \mathrm{KCl}, 1.0 \mathrm{MgSO}_{4}, 2.5 \mathrm{CaCl}_{2}, 1.25$ $\mathrm{NaH}_{2} \mathrm{PO}_{4}, 23 \mathrm{NaHCO}_{3}, 10$ glucose, and $0.05 \mathrm{Na}$-metabisulfite, an antioxidant to prevent oxidation of dopaminergic reagents. Temperature was $29 \pm 1^{\circ} \mathrm{C}$. Whole-cell recordings were obtained with Multiclamp 700B amplifier and Digidata 1440A (Molecular Devices). Neurons were visualized under differential interference contrast optics and infrared and epifluorescent illumination with a CCD camera (Rolera-XR, QImaging), and recorded using 3-5 $\mathrm{M} \Omega$ pipettes filled with $\mathrm{Cs}^{+}$-based internal solution containing the following (in $\mathrm{mM}$ ): $130 \mathrm{Cs}$-methanesulfonate, $5 \mathrm{NaCl}, 1 \mathrm{MgCl}_{2}, 0.2$ EGTA, 10 HEPES, 2 ATP-Mg, 0.1 GTP-Na, and 5 QX314, pH 7.3, osmolarity 285 mOsm. Depolarization-induced suppression of inhibition was tested using a high- $\mathrm{Cl}^{-}$internal solution containing the following (in $\mathrm{mm}$ ): $100 \mathrm{Cs}$-methanesulfonate, $60 \mathrm{CsCl}, 1$ $\mathrm{MgCl}_{2}$, 0.2 EGTA, 10 HEPES, 2 ATP-Mg, 0.1 GTP-Na, and 5 QX314. Series resistance $\left(R_{s} ; 10-20 M \Omega\right)$ was monitored throughout the experiments. Data were not included if $\mathrm{R}_{\mathrm{s}}$ changed $>15 \%$ during recording. $470 \mathrm{~nm}$ light pulses were generated using a high-power LED (M470L2) and driver (Thorlabs), and were delivered through a $40 \times$ objective lens (Carl Zeiss). The effect of DA was determined as the ratio between the mean IPSC amplitude during the last 2 min of DA application and the baseline.

All chemicals were obtained from Tocris Bioscience, except that Nametabisulfite was from Sigma, $\omega$-agatoxin IVA was from Bachem, and $\mathrm{Rp}-8-\mathrm{OH}$-cAMP was from Axxora.

Fluorescence immunohistochemistry. To verify expression of ChR2 in PV-immunoreactive neurons 3 weeks after surgery, mice were intracardially perfused with $4 \%$ paraformaldehyde (PFA) dissolved in PBS. Brains were then postfixed in PFA overnight and sliced into $75 \mu \mathrm{m}$ sections using a vibratome. Slices were incubated for $1 \mathrm{~h}$ in a blocking solution containing $1.5 \%$ normal goat serum in PBS with $0.2 \%$ Triton $\mathrm{X}-100$ (PBS-T). Slices were then incubated overnight at $4^{\circ} \mathrm{C}$ with mouse anti-PV monoclonal antibody (1:1000) (Sigma). Sections were washed $3 \times 15$ min in PBS-T followed by $2-4 \mathrm{~h}$ incubation with Cy 5 anti-mouse secondary antibody (1:400) (Jackson Laboratories) at room temperature. Confocal images were captured with Carl Zeiss LSM510 microscope.

Statistical analysis. Data are presented as mean \pm SEM. Statistical comparisons were performed using a two-tailed paired $t$ test unless stated otherwise, and differences were considered significant with $p<0.05$.

\section{Results}

Selective ChR2-mediated photoactivation of PV-INs in BLA BLA injection of $P V$-Cre transgenic mice with an AAV containing Cre-activated ChR2-tdTomato gene resulted in red fluorescence in both soma and axonal arbors of infected neurons (Fig. 1A). Immunostaining confirmed that ChR2 was selectively expressed in PV-INs, as all ChR2-tdTomato neurons coexpressed parvalbumin, although not all PV-INs expressed ChR2-tdTomato (Fig. 1A). Short pulses of $470 \mathrm{~nm}$ light depolarized the infected cells and triggered single action potentials (Fig. $1 B$ ), whereas continuous photostimulation caused high-frequency firing (Fig. $1 B$ ) similar to the typical fast-spiking of PV-INs induced by prolonged current injection (Fig. $1 B$ ).

To confirm functional activation of synapses between PV-INs and PNs, we recorded from PNs held at the membrane potential of $+10 \mathrm{mV}$. Short pulses of photostimulation (0.1-1 ms) evoked strong IPSCs, which were suppressed by the $\mathrm{GABA}_{\mathrm{A}}$ receptor antagonist picrotoxin $(100 \mu \mathrm{M})($ from $1.0 \pm 0.2 \mathrm{nA}$ to $0.02 \pm 0.01$ $n A, n=5, p<0.01$ ) (Fig. $1 C$ ). It has been shown that GABA release from PV-INs is mediated by $\mathrm{P} / \mathrm{Q}$ type $\mathrm{Ca}^{2+}$ channels (Wilson et al., 2001; Kruglikov and Rudy, 2008). Consistently, light-evoked IPSCs in BLA PNs were dramatically suppressed by specific $\mathrm{P} / \mathrm{Q}$ type $\mathrm{Ca}^{2+}$ channel blocker $\omega$-agatoxin IVA $(0.5 \mu \mathrm{M})$ (from $1.5 \pm 0.3 \mathrm{nA}$ to $0.09 \pm 0.03 \mathrm{nA}, n=4, p<0.05$ ) (Fig. $1 D$ ). Another typical property of the PV-IN-PN synapses is the lack of depolarization-induced suppression of inhibition (DSI) due to the absence of presynaptic cannabinoid receptor 1 (Wilson et al., 2001). As expected, light-induced IPSCs in BLA did not show any DSI ( $96 \pm 3 \%$ of baseline after $6 \mathrm{~s}$ depolarization to $0 \mathrm{mV}, p>$ $0.05, n=5$ ) (Fig. $1 E$ ). Together, our data indicate that GABAergic synapses activated by ChR2 in PV-Cre transgenic mice originate from PV-INs.

\section{DA suppresses GABAergic transmission from PV-INs to principal neurons, but not to interneurons}

It has been reported that DA disinhibits BLA by suppressing inhibitory input to PNs while enhancing FFI to INs (Bissière et al., 2003). Given that PV-INs are the major group of BLA INs (McDonald and Mascagni, 2001), we tested a hypothesis that DA modulates the synaptic transmission from PV-INs to their postsynaptic targets in a cell type-specific manner.

To assess connectivity from PV-INs to INs, we expressed ChR2-tdTomato in the BLA of Cre-PV/GAD67-GFP mice, in 

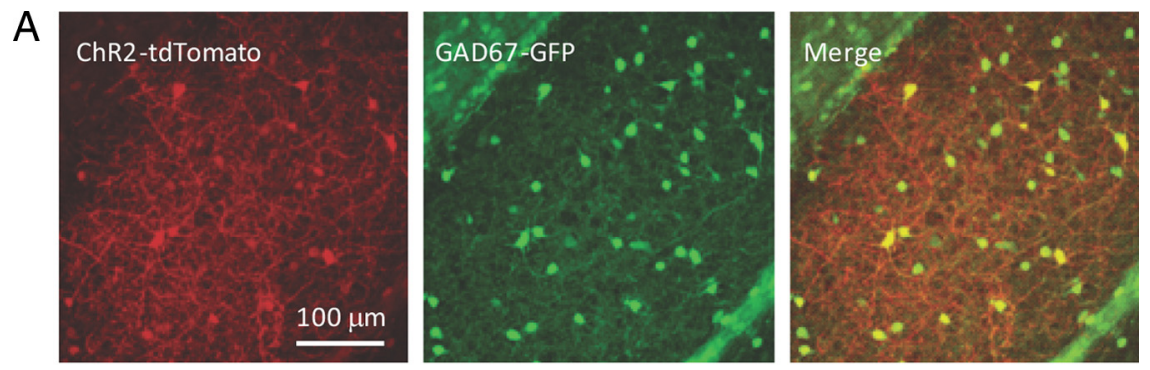

B
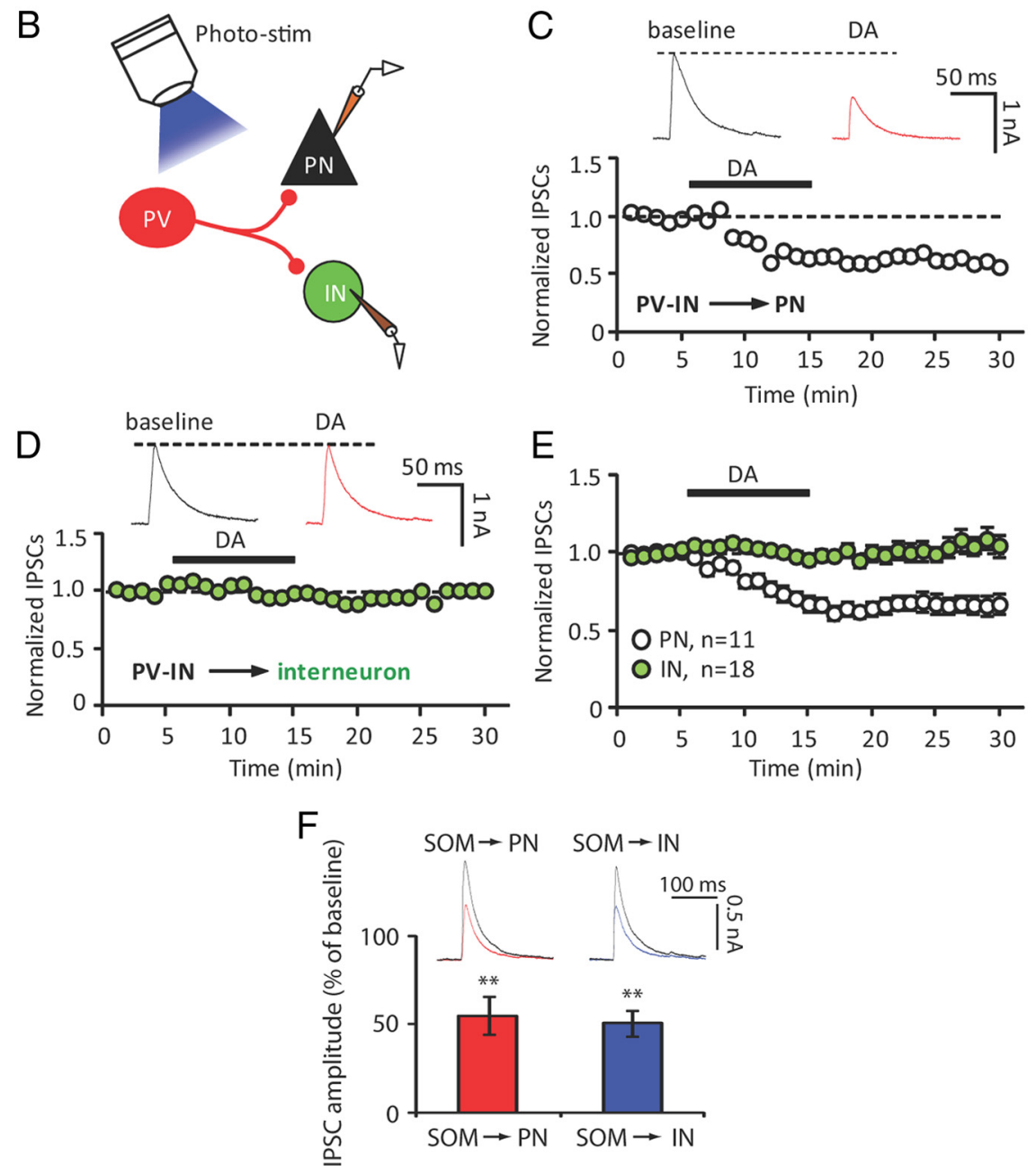

Figure 2. Selective modulation of GABAergic transmission from PV-INs to PNs by DA. $A$, Expression of ChR2 (left) in BLA of Cre-PV/GAD67-GFP mice (middle). B, Recording configuration. $\boldsymbol{C}$, Top, example IPSCs evoked in a BLA pyramidal neuron by photostimulation (Photo-stim) before (black) and after (red) DA application. Bottom, Time course of the IPSC amplitude in the same cell. D, Top, Example IPSCs evoked in a BLA INs by photostimulation before (black) and after (red) DA application. Bottom, Time course of the IPSCs amplitude in the same cell. $\boldsymbol{E}$, Summarized data for the effects of DA in BLA PNs and INs. $\boldsymbol{F}$, DA effect on GABAergic neurotransmission from SOM-INs to PNs and INs. The red and blue traces indicate IPSC after DA application. ${ }^{* *} p<0.01$ when compared with baseline.

which interneurons can be identified by green fluorescence (Fig. $2 A)$. First, we recorded from PNs and induced GABA release from PV-INs by photostimulation (Fig. $2 B$ ). Bath application of $50 \mu \mathrm{M}$ DA (which provided close to the maximal effect of DA: data not shown) effectively reduced the IPSCs amplitude in PNs to $63 \pm 4 \%$ of baseline $(n=11, p<0.001)$ (Fig. $2 C, E)$. Thus, PV-INs are involved in dopaminergic disinhibition of BLA PNs. In contrast to its effect in PNs, DA did not reduce IPSC amplitude in INs $(101 \pm 3 \%$ of baseline, $p>0.05, n=18)$ (Fig. $2 D, E)$, indicating that DA modulates GABAergic transmission from PV-INs in a postsynaptic cell typespecific manner. However, when we stimulated somatostatin (SOM)-positive INs, DA suppressed IPSC amplitude in both PNs $(55 \pm 10 \%$ of baseline, $n=5, p<$ 0.01 ) and INs ( $51 \pm 7 \%$ of baseline, $n=5$, $p<0.01$ ) (Fig. $2 F$ ), suggesting distinct effects of DA on GABA release from different subtypes of INs.

\section{Presynaptic $D_{2}$ receptors mediate the inhibitory effect of DA in principal neurons}

Dopaminergic projections from the midbrain to BLA target both PNs (Muller et al., 2009) and PV-INs (Pinard et al., 2008); therefore, our next experiments were designed to determine the action locus of DA in PV-INs projections to PNs. First, we tested paired-pulse ratio (PPR) by two consecutive pulses of light at an interval of $100 \mathrm{~ms}$, and this resulted in paired-pulse depression (Fig. 3A), which is typical for PV-IN synapses (Hefft and Jonas, 2005). Application of DA increased PPR from $0.78 \pm 0.13$ to $1.1 \pm 0.16(n=$ $5, p<0.05$ ) (Fig. 3A), suggesting involvement of presynaptic mechanisms in the inhibitory effects of DA. To examine possible postsynaptic effects of DA, we evoked $\mathrm{GABA}_{\mathrm{A}}$ receptor currents by local puffing of $\mathrm{GABA}_{\mathrm{A}}$ receptor agonist muscimol $(50 \mu \mathrm{M})$. However, DA did not change those currents $(95 \pm 7 \%$ of baseline, $n=7, p>0.05$ ) (Fig. 3B), indicating that DA does not affect postsynaptic $\mathrm{GABA}_{\mathrm{A}}$ receptors function. Thus, DA suppresses IPSCs in PNs by reducing presynaptic GABA release.

Next we tested the effect of DA on photoexcitability of PV-INs expressing ChR2 in current-clamp mode. DA significantly depolarized membrane potential from $-63 \pm 1.4$ to $-56 \pm 1.0 \mathrm{mV}(n=8, p<$ $0.01)$ and reduced input resistance from $138 \pm 11$ to $112 \pm 15 \mathrm{M} \Omega(n=8, p<$ 0.05 ), but did not decrease the number of spikes evoked by $100 \mathrm{~ms}$ pulses of suprathreshold photostimulation (from $6.3 \pm 1.5$ to $6.6 \pm 1.6, n=8, p>0.05$ ) (Fig. $3 C$ ), indicating that the effect of DA on GABA release to $\mathrm{PNs}$ did not result from changes in the somatic excitability of PV-INs.

We next examined the role of $D_{1}$ and $D_{2}$ receptors, which are both expressed in BLA (Pinto and Sesack, 2008), in the inhibitory effects of DA. DA inhibition was not affected by specific $D_{1}$ receptor antagonist SCH23390 $(10 \mu \mathrm{M})\left(\mathrm{DA}^{*} \mathrm{SCH} 23390\right.$ interaction: $F_{(1,15)}=0.01, p>0.05$, repeated-measures ANOVA). In the presence of SCH23390, DA inhibited IPSCs to $69 \pm 1 \%$ of the pre-DA level ( $p<0.05, n=6)$. In contrast, IPSC inhibition by DA was abolished by the $D_{2}$ receptor antagonist raclopride (10 $\mu \mathrm{M})\left(F_{(1,18)}=7.6, p<0.01\right.$ for $\mathrm{DA}^{\star}$ raclopride interaction, repeated-measures ANOVA). In the presence of raclopride, DA 
A
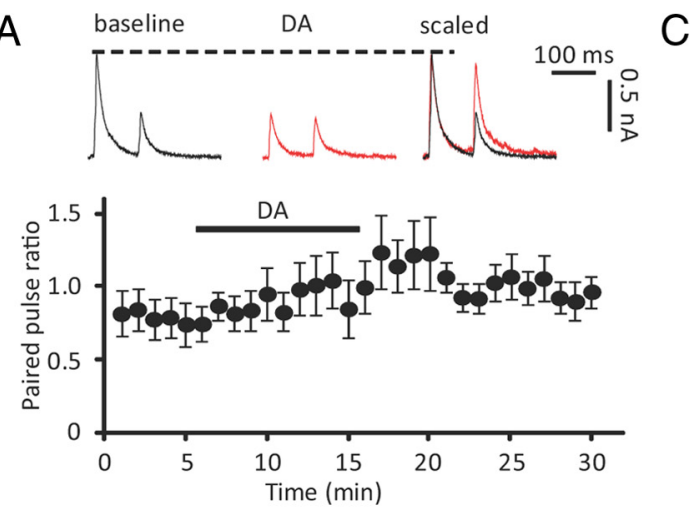

B

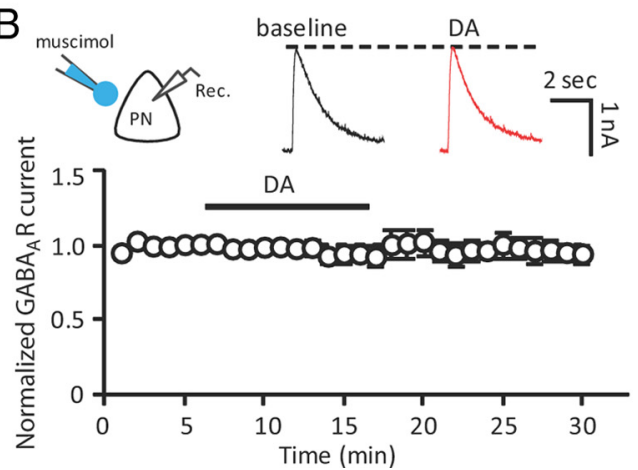

C
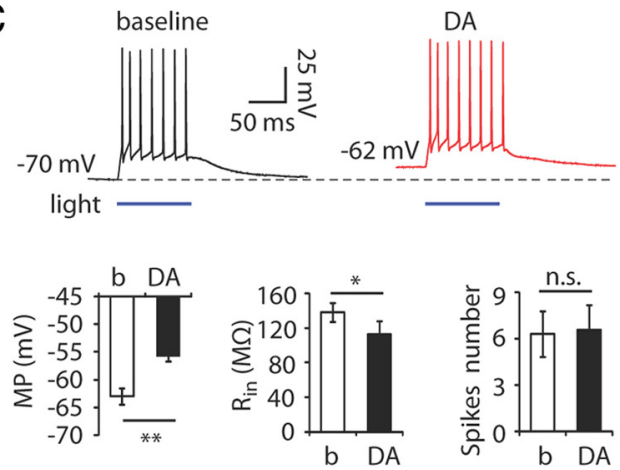

D

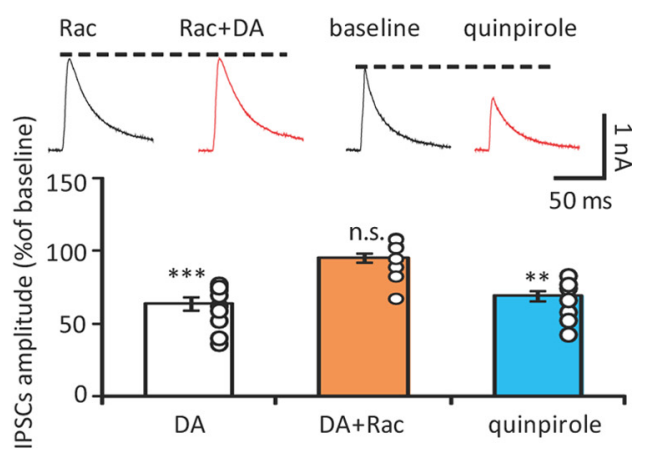

Figure 3. Presynaptic $D_{2}$ receptor mediates the inhibitory effects of DA in PV-IN projections to PNs. $A$, Top, Example traces of synaptic responses to paired-pulse stimulation before (black) and after (red) DA application. Bottom, Summary graph shows changes of paired-pulse ratio during DA application. $B$, Top, Example traces of muscimol-puffing-induced GABA $A_{A}$ receptor current before (black) and after (red) DA application. Bottom, Summary graph shows muscimol-induced current during DA application. C, Top, Firing pattern of a PV-IN expressing ChR2 upon photostimulation (light) before and after DA application. Bottom, Effects of DA on membrane potential (MP; left), input resistance ( $R_{\text {in }}$; middle), and number of spikes (right) in PV-INs. D, Top, Example IPSC traces before and after DA application in the presence of raclopride (Rac), and the IPSC traces before and after application of quinpirole. Bottom, Summary bar graph shows inhibition of IPSC by DA, lack of such inhibition in the presence of raclopride, and inhibition by quinpirole. Each dot represents a single cell. ${ }^{* *} p<0.01,{ }^{* * *} p<0.005$. n.s., Nonsignificant, when compared with baseline.

had a negligible inhibitory effect ( $95 \pm 3 \%$ of pre-DA level, $n=9$, $p>0.05$ ) (Fig. $3 D$ ). Consistently, specific $\mathrm{D}_{2}$ receptor agonist quinpirole $(10 \mu \mathrm{M})$ mimicked DA inhibition by suppressing IPSCs in PNs (67 $\pm 6 \%$ of baseline, $n=7, p<0.01$ ) (Fig. $3 D)$. Thus, DA inhibits GABA release from PV-INs to PNs mainly via presynaptic $\mathrm{D}_{2}$ receptors.

\section{cAMP-dependent signaling mediates the inhibitory effects of DA}

To investigate the transduction mechanisms underlying dopaminergic inhibition in PNs, we evaluated the contribution of G-protein-gated inwardly rectifying $\mathrm{K}^{+}$(GIRK) channels and cAMP-dependent signaling cascade, both of which are regulated by $\mathrm{D}_{2}$ receptor (Beaulieu and Gainetdinov, 2011). In the presence of the specific GIRK channel blocker tertiapin-Q $(200 \mathrm{nM}$ ), DA inhibited IPSCs (from $1.5 \pm 0.15$ to $0.9 \pm 0.07$ $\mathrm{nA}, n=5, p<0.05$ ) (Fig. $4 A$ ), suggesting that the GIRK channel is not involved in the DA-induced inhibition. In contrast, Rp-cAMP $(100 \mu \mathrm{M})$, a nonhydrolyzable competitor of cAMP, abolished the inhibitory effect of DA (from $0.9 \pm 0.1$ to $0.89 \pm 0.1 \mathrm{nA}, n=6, p>0.05$ ) (Fig. $4 B$ ). Moreover, H-89 (10 $\mu \mathrm{M})$, a protein kinase A (PKA) inhibitor, also prevented DA inhibition of IPSCs in PNs (from $1.6 \pm 0.2 \mathrm{nA}$ to $1.6 \pm 0.2 \mathrm{nA}$, $n=5, p>0.05$ ) (Fig. 4C), indicating that DA inhibition is due to the suppression of cAMP-PKA cascade upon $\mathrm{D}_{2}$ receptor activation in PV-INs.

\section{Gating of GABA release from PV-INs by cAMP}

We next investigated the role of cAMP-dependent signaling in controlling GABA release from PV-INs. Direct suppression of
cAMP-dependent process by bath application of Rp-cAMP (100 $\mu \mathrm{M}$ ) dramatically reduced IPSC amplitude in PNs (from $1.4 \pm$ 0.2 to $0.9 \pm 0.1 \mathrm{nA}, n=6, p<0.01$ ) (Fig. $4 D$ ), suggesting that GABA release from PV-INs to PNs is sustained by basal cAMPdependent signaling. In contrast to its effect in PNs, Rp-cAMP did not alter IPSC amplitude in INs (from $0.7 \pm 0.08$ to $0.7 \pm 0.1$ $\mathrm{nA}, n=7, p>0.05$ ) (Fig. $4 E$ ), suggesting that, at the basal state, cAMP-dependent signaling is not involved in GABA release from PV-INs to INs. Furthermore, bath application of forskolin (50 $\mu \mathrm{M})$, an adenylate cyclase activator, did not change IPSC amplitudes in INs either (from $0.9 \pm 0.1$ to $1.0 \pm 0.1 \mathrm{nA}, n=8, p>$ 0.05 ) (Fig. $4 F$ ), but increased the GABA release induced by local electrical stimulation (from $0.7 \pm 0.2$ to $1.0 \pm 0.2 \mathrm{nA}, n=8, p<$ 0.01 ), suggesting that control of GABA release by cAMPdependent signaling is selectively absent in the synapses from PV-INs to BLA INs. In these experiments, postsynaptic effects of Rp-cAMP were ruled out by intracellular application of a membrane-impermeable cAMP analog Rp-8-OH-cAMP (4 mM) through a recording pipette. The above results indicate that GABA release from PV-INs to BLA PNs and INs is differentially controlled by a cAMP-dependent process, which might be the major mechanism underlying the target-specific effect of DA in BLA.

\section{Discussion}

Here, we investigate a circuit mechanism of dopaminergic disinhibition in BLA, focusing on DA modulation of GABA release from local PV-INs. We find that DA suppresses GABA release from PV-INs in a target cell-specific manner-DA suppresses the release to PNs, but not to INs. This result indicates the PV-INs are 

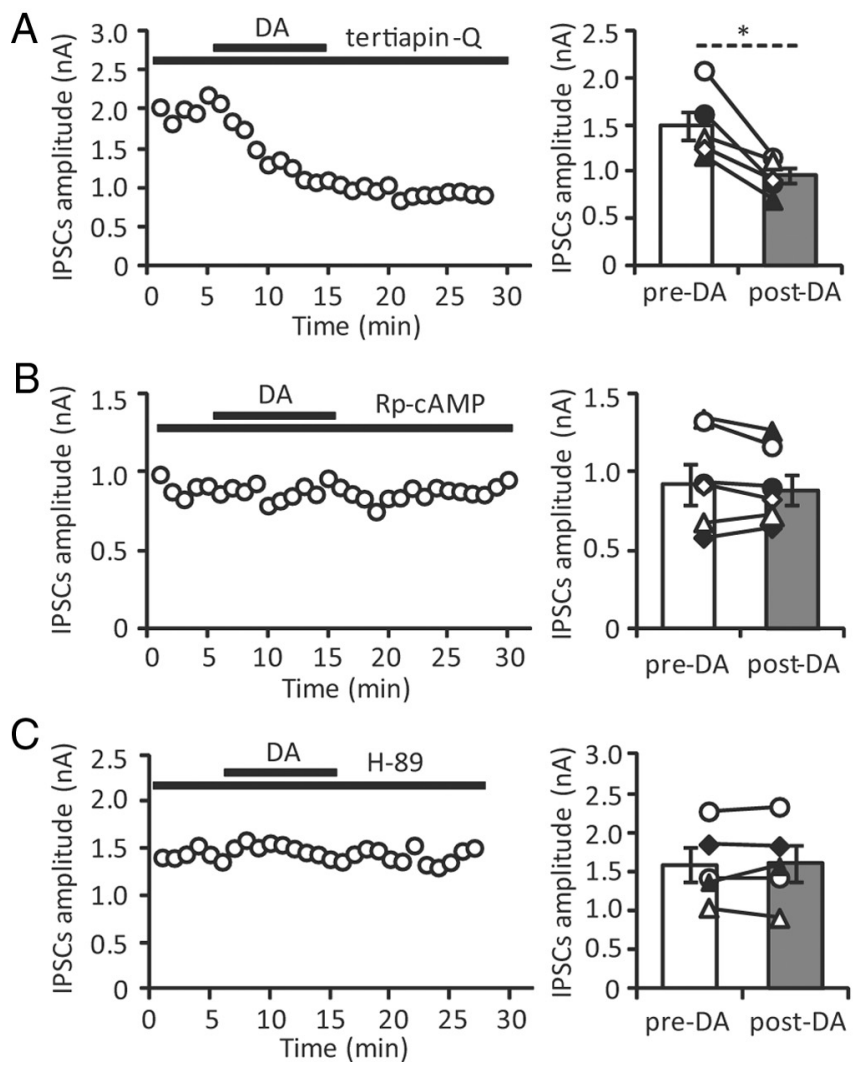
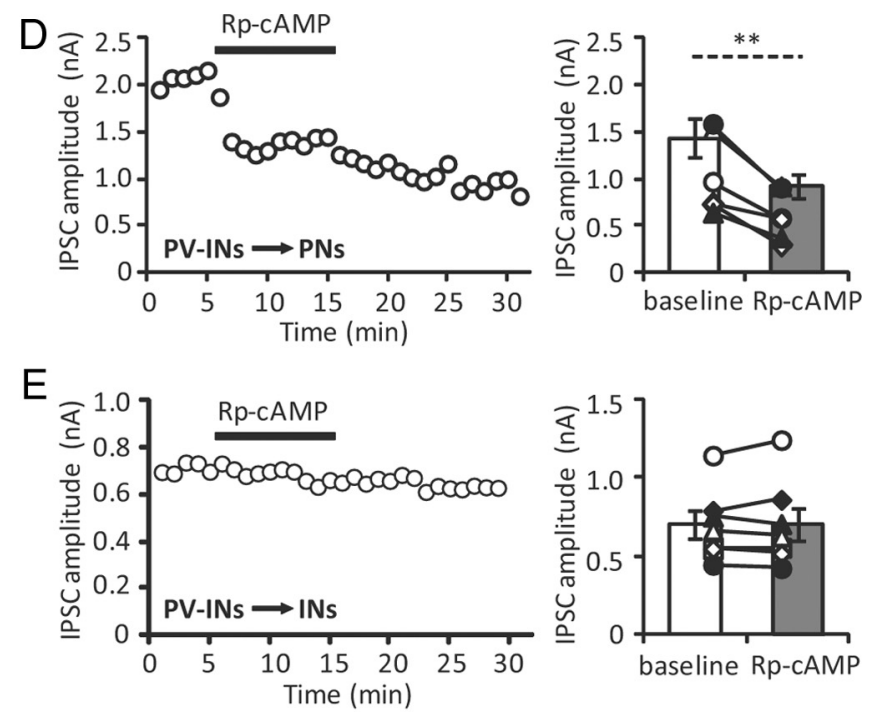

F
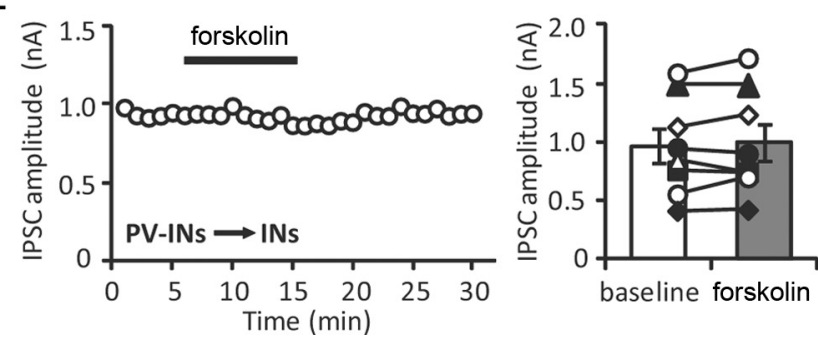

Figure 4. The role of cAMP-dependent signaling in target-specific inhibition of GABA release from PV-INs by DA. $A$, Specific GIRK channel inhibitor tertiapin- $Q$ did not interfere with DA inhibition of IPSCs in PNs. Left, Time course of IPSC amplitude from an example cell. Right, Summary graph showing the effect of DA after blockade of GIRK. Each symbol represents a single neuron. $\boldsymbol{B}$, $\boldsymbol{C}$, Inhibitory effect of DA was blocked by CAMP competitor Rp-CAMP $(\boldsymbol{B})$ and by PKA inhibitor H-89 (C). D, E, Rp-CAMP alone reduced the IPSC amplitude in PNs (D) but not in INs (E). $\boldsymbol{F}$, Adenylate cyclase activator forskolin did not affect GABA release from PV-INs to INs. ${ }^{*} p<0.05,{ }^{* *} p<0.01$.

one component of the amygdala disinhibition by DA, in which PV-INs decrease inhibition of PNs, but keep inhibition of interneurons intact. Finally, we show that cAMP-dependent signaling affects GABA release from the PV-IN terminals that target PNs, but not INs, which provides one mechanism for the targetspecific action of DA. Given that distinct subtypes of INs differ in the firing patterns and in the subcellular domain of PNs that they target, it is expected that each IN subtype is specialized in controlling a particular aspect of $\mathrm{PN}$ activity. A recent study supports this notion by showing that distinct subtypes of BLA interneurons are differentially modulated by external stimuli (Bienvenu et al., 2012), which might indicate their differential involvement in BLA disinhibition. Therefore, to obtain a mechanistic understanding of BLA disinhibition, it is necessary to analyze DA effects on inhibitory synapses originating from defined IN classes. Previous studies documented that DA suppresses FFI in BLA PNs (Bissière et al., 2003; Marowsky et al., 2005). Here, we focused on a specific interneuronal subtype, the PV-INs, which we activate selectively as a group using an optogenetics technique. We find that DA suppresses GABA release from PV-INs to PNs. This observation is consistent with the notion that PV-INs contribute to FFI in PNs (Woodruff and Sah, 2007; Pape and Pare, 2010). Surprisingly, despite earlier reports of DA enhancing FFI in BLA INs (Bissière et al., 2003), we did not find any effect of DA on GABAergic transmission from PV-INs to BLA INs. Furthermore, DA suppresses GABAergic transmission from SOM-IN to INs, which argues that the enhancement of IPSC in INs by DA is mediated by an unknown group of INs that are PV-negative and SOM-negative cells. Altogether, the existing evidence indicates that DA effects are unique among different IN subtypes.
Accumulating data indicate that PV-INs are not a homogeneous class, they include basket cells providing perisomatic inhibition but showing no coupling with hippocampal theta, the axo-axonic cells activated by noxious stimuli, and the AStria-projecting neurons suppressed by noxious stimuli (Bienvenu et al., 2012). Since in our study IPSCs represent the cumulative activity of all PV-INs with ChR2, we do not rule out a possibility that a certain subgroup of PV-INs does not contribute to the observed effects of DA. None of our data rules out the contribution of other subtypes of INs in BLA disinhibition by DA, such as the paracapsular intercalated cells (Marowsky et al., 2005) or another unknown type of IN through which DA increases the inhibition of INs (Bissière et al., 2003). Nevertheless, thorough analyses of neuromodulation of inhibitory synapses from distinct IN subtypes using interneuron-specific Cre lines will help understand how different subclasses of interneurons interact to ultimately control BLA output.

The target cell-specific DA effect on GABA release from PV-INs is a plausible explanation of DA disinhibition of the amygdala; yet, it raises a mechanistic question-how it can be achieved. There are two potential mechanisms: (1) a specific subgroup of PV-INs with $\mathrm{D}_{2}$ receptor sensitivity projects to $\mathrm{PNs}$, but not to INs; and (2) presynaptic $D_{2}$ receptor differentially regulates GABA release from distinct terminals along the same axon of PV-INs, depending on the postsynaptic target. Importantly, our data suggest that synapses between PV-INs are not modulated by DA, because we did not see an effect of DA on IPSCs in GAD67-GFP-positive cells, a significant portion of which are PV-INs. Therefore, if the first mechanism was correct, the $\mathrm{D}_{2}$-sensitive PV-INs should not make any connections among themselves; however, the existence of such a special subtype of PV-INs is very unlikely, given the fact 
that PV-INs are highly connected to one another (Muller et al., 2005; Woodruff and Sah, 2007). Moreover, it has been well documented that regulation of neurotransmitter release and synaptic plasticity can be compartmentalized at divergent release sites along a common axon (Markram et al., 1998; Scanziani et al., 1998), which is consistent with the second mechanism.

As for molecular and cellular mechanisms of the compartmentalization, the target cell-specific DA effect could be attributed to differential expression of $\mathrm{D}_{2}$ receptors or distinct intracellular signaling at different presynaptic terminals. We explore the latter possibility by examining the signal transduction downstream $\mathrm{D}_{2}$ receptor. Consistent with the earlier observations that basal cAMP/PKA signaling is involved in GABA release in the hippocampus and prefrontal cortex (Chevaleyre et al., 2007; Chiu et al., 2010), we find that GABA release from PV-INs to PNs in BLA is controlled by basal activity of cAMP-dependent signaling. However, GABA release from PV-INs to BLA INs is sensitive to neither suppression nor activation of cAMP signaling. Thus, cAMP signaling gates GABA release from PV-INs differently, depending on postsynaptic targets, and accounts for the target cell-specific DA effect in BLA.

While mechanisms that contribute to the gating of GABA release by cAMP remain unclear, exploring the downstream targets of cAMP-dependent cascade in PV-IN terminals projecting to PNs, such as voltage-gated $\mathrm{Ca}^{2+}$ channels and presynaptic active zone proteins, like RIM1 $\alpha$ (Chevaleyre et al., 2007), will help in understanding the principles underlying the fine-tuning of the amygdala interneuronal circuit by neuromodulators.

\section{References}

Aponte Y, Atasoy D, Sternson SM (2011) AGRP neurons are sufficient to orchestrate feeding behavior rapidly and without training. Nat Neurosci 14:351-355. CrossRef Medline

Asan E (1997) Ultrastructural features of tyrosine-hydroxylase-immunoreactive afferents and their targets in the rat amygdala. Cell Tissue Res 288:449469. CrossRef Medline

Beaulieu JM, Gainetdinov RR (2011) The physiology, signaling, and pharmacology of dopamine receptors. Pharmacol Rev 63:182-217. CrossRef Medline

Bienvenu TC, Busti D, Magill PJ, Ferraguti F, Capogna M (2012) Cell-typespecific recruitment of amygdala interneurons to hippocampal theta rhythm and noxious stimuli in vivo. Neuron 74:1059-1074. CrossRef Medline

Bissière S, Humeau Y, Lüthi A (2003) Dopamine gates LTP induction in lateral amygdala by suppressing feedforward inhibition. Nat Neurosci 6:587-592. CrossRef Medline

Chevaleyre V, Heifets BD, Kaeser PS, Südhof TC, Purpura DP, Castillo PE (2007) Endocannabinoid-mediated long-term plasticity requires cAMP/ PKA signaling and RIM1alpha. Neuron 54:801-812. CrossRef Medline

Chiu CQ, Puente N, Grandes P, Castillo PE (2010) Dopaminergic modulation of endocannabinoid-mediated plasticity at GABAergic synapses in the prefrontal cortex. J Neurosci 30:7236-7248. CrossRef Medline

Fadok JP, Dickerson TM, Palmiter RD (2009) Dopamine is necessary for cue-dependent fear conditioning. J Neurosci 29:11089-11097. CrossRef Medline

Freund TF, Katona I (2007) Perisomatic inhibition. Neuron 56:33-42. CrossRef Medline

Harmer CJ, Phillips GD (1999) Enhanced dopamine efflux in the amygdala by a predictive, but not a non-predictive, stimulus: facilitation by prior repeated D-amphetamine. Neuroscience 90:119-130. CrossRef Medline

Hefft S, Jonas P (2005) Asynchronous GABA release generates long-lasting inhibition at a hippocampal interneuron-principal neuron synapse. Nat Neurosci 8:1319-1328. CrossRef Medline

Hippenmeyer S, Vrieseling E, Sigrist M, Portmann T, Laengle C, Ladle DR, Arber S (2005) A developmental switch in the response of DRG neurons to ETS transcription factor signaling. PLoS Biol 3:e159. CrossRef Medline
Inglis FM, Moghaddam B (1999) Dopaminergic innervation of the amygdala is highly responsive to stress. J Neurochem 72:1088-1094. CrossRef Medline

Kruglikov I, Rudy B (2008) Perisomatic GABA release and thalamocortical integration onto neocortical excitatory cells are regulated by neuromodulators. Neuron 58:911-924. CrossRef Medline

LeDoux JE (2000) Emotion circuits in the brain. Annu Rev Neurosci 23: 155-184. CrossRef Medline

Markram H, Wang Y, Tsodyks M (1998) Differential signaling via the same axon of neocortical pyramidal neurons. Proc Natl Acad Sci U S A 95: 5323-5328. CrossRef Medline

Marowsky A, Yanagawa Y, Obata K, Vogt KE (2005) A specialized subclass of interneurons mediates dopaminergic facilitation of amygdala function. Neuron 48:1025-1037. CrossRef Medline

McDonald AJ, Betette RL (2001) Parvalbumin-containing neurons in the rat basolateral amygdala: morphology and co-localization of CalbindinD(28k). Neuroscience 102:413-425. CrossRef Medline

McDonald AJ, Mascagni F (2001) Colocalization of calcium-binding proteins and GABA in neurons of the rat basolateral amygdala. Neuroscience 105:681-693. CrossRef Medline

Muller JF, Mascagni F, McDonald AJ (2005) Coupled networks of parvalbumin-immunoreactive interneurons in the rat basolateral amygdala. J Neurosci 25:7366-7376. CrossRef Medline

Muller JF, Mascagni F, McDonald AJ (2009) Dopaminergic innervation of pyramidal cells in the rat basolateral amygdala. Brain Struct Funct 213: 275-288. CrossRef Medline

Pape HC, Pare D (2010) Plastic synaptic networks of the amygdala for the acquisition, expression, and extinction of conditioned fear. Physiol Rev 90:419-463. CrossRef Medline

Pinard CR, Muller JF, Mascagni F, McDonald AJ (2008) Dopaminergic innervation of interneurons in the rat basolateral amygdala. Neuroscience 157:850-863. CrossRef Medline

Pinto A, Sesack SR (2008) Ultrastructural analysis of prefrontal cortical inputs to the rat amygdala: spatial relationships to presumed dopamine axons and D1 and D2 receptors. Brain Struct Funct 213:159-175. CrossRef Medline

Rosenkranz JA, Grace AA (2001) Dopamine attenuates prefrontal cortical suppression of sensory inputs to the basolateral amygdala of rats. J Neurosci 21:4090-4103. Medline

Scanziani M, Gähwiler BH, Charpak S (1998) Target cell-specific modulation of transmitter release at terminals from a single axon. Proc Natl Acad Sci U S A 95:12004-12009. CrossRef Medline

Sosulina L, Graebenitz S, Pape HC (2010) GABAergic interneurons in the mouse lateral amygdala: a classification study. J Neurophysiol 104:617-626. CrossRef Medline

Spampanato J, Polepalli J, Sah P (2011) Interneurons in the basolateral amygdala. Neuropharmacology 60:765-773. CrossRef Medline

Suzuki T, Ishigooka J, Watanabe S, Miyaoka H (2002) Enhancement of delayed release of dopamine in the amygdala induced by conditioned fear stress in methamphetamine-sensitized rats. Eur J Pharmacol 435:59-65. CrossRef Medline

Tamamaki N, Yanagawa Y, Tomioka R, Miyazaki J, Obata K, Kaneko T (2003) Green fluorescent protein expression and colocalization with calretinin, parvalbumin, and somatostatin in the GAD67-GFP knock-in mouse. J Comp Neurol 467:60-79. CrossRef Medline

Taniguchi H, He M, Wu P, Kim S, Paik R, Sugino K, Kvitsani D, Fu Y, Lu J, Lin Y, Miyoshi G, Shima Y, Fishell G, Nelson SB, Huang ZJ (2011) A resource of Cre driver lines for genetic targeting of GABAergic neurons in cerebral cortex. Neuron 71:995-1013. CrossRef Medline

Wilson RI, Kunos G, Nicoll RA (2001) Presynaptic specificity of endocannabinoid signaling in the hippocampus. Neuron 31:453-462. CrossRef Medline

Woodruff AR, Sah P (2007) Networks of parvalbumin-positive interneurons in the basolateral amygdala. J Neurosci 27:553-563. CrossRef Medline

Zhang F, Gradinaru V, Adamantidis AR, Durand R, Airan RD, de Lecea L, Deisseroth K (2010) Optogenetic interrogation of neural circuits: technology for probing mammalian brain structures. Nat Protoc 5:439-456. CrossRef Medline 